\title{
Adolescent Interpersonal \\ Communication Patterns
}

S Grobler
D Cur

Rand Afrikaans University

\&

CPH Myburgh

D Ed (Psychology of Education)

Educational Sciences

Rand Afrikaans University

\&

\section{Poggenpoel}

Ph D

Professor : Department of Nursing Science

Rand Afrikaans University
"... addescents have the ability to formulate

\section{constructive}

interpersonal

communication skills if

they are given the

appurtunity and are fascilitated correctly."

\begin{abstract}
Adolescents are admitted to psychiatric wards presenting with psychiatric problems which are essentially secondary to problematic interpersonal relationships. Successful interpersonal relationships however depend on effective interpersonal communication. Therefore the aim of research on adolescent interpersonal communication was to explore and describe the interpersonal communication patterns of adolescents and to develop an interpersonal communication skills approach to facilitate adolescent interpersonal communication skills within a training programme for adolescents. In this article however attention will be given to the description of the interpersonal communication patterns of adolescents. The target population of the research was 17 year old adolescents. The research consisted of a pre-phase where two contextual scenarios were formulated within group discussions with adolescents. During phase one of the research these scenarios were used to obtain video taped role plays from pairs of adolescents of the target population which were transcribed for data gathering purposes. Written dialogues were also obtained from each pair of adolescents on the same scenarios used for triangulation purposes. During phase two of the research the data was analysed according to Tesch's method and a literature control was done to verify the results. Guba's model for the trustworthiness of qualitative research was used.

Four recurrent interpersonal communication patterns were identified, namely:

- Recurrent patterns of defocusing and externalizing the topic under discussion;

- Recurrent patterns of struggling for power;

- Recurrent patterns of not listening; and

- Recurrent patterns of focusing only on cognitive contents of messages and not on feelings.
\end{abstract}

The research showed that adolescents have ineffective interpersonal communication patterns. Recommendations were made to facilitate adolescent interpersonal communication within an interpersonal communication skills approach.

\section{Opsomming}

Met opname tot psigiatriese eenhede presenteer adolessente met psigiatriese probleme wat sekondêr is tot problematiese interpersoonlike verhoudings. Die geslaagdheid van interpersoonlike verhoudings is egter afhanklik van effektiewe interpersoonlike kommunikasie. Om hierdie rede was die doel van navorsing op adolessente interpersoonlike kommunikasie om die interpersoonlike kommunikasiepatrone van adolessente te verken en te beskryf. Hiervolgens is ' $n$ interpersoonlike kommunikasievaardigheidsbenadering ontwikkel om adolessente se interpersoonlike kommunikasievaardighede te fasiliteer binne in opleidingsprogram aan adolessente. Hierdie artikel word egter slegs gewy aan die beskrywing van die interpersoonlike kommunikasievaardigheidspatrone van adolessente wat betrek is vir hierdie navorsing. Die teikenpopulasie van die navorsing was 17-jarige adolessente. Die navorsing het bestaan uit ' $n$ voorfase waar 2 kontekstuele scenarios geformuleer is deur groepsgesprekvoeringe met adolessente van die teikenpopulasie. Gedurende fase 1 van die navorsing is data insameling gedoen deur hierdie scenarios te gebruik om rollespelle te verkry van pare adolessente van die teikenpopulasie, dit op videoband op te neem en te transkribeer. Vir trianguleringsdoeleindes is ook geskrewe dialoë verkry van dieselfde pare adolessente wat die rollespelle uitgevoer het. Gedurende fase 2 is data analise gedoen deur die gebruikmaking van Tesch se metode van data analise en ' $n$ literatuurkontrole is uitgevoer om resultate te verifieer. Guba se model vir vertrouenswaardigheid van kwalitatiewe navorsing is gebruik.

Vier herhalende interpersoonlike kommunikasiepatrone is geidentifiseer, naamlik: 
- Herhalende patrone van defokus en eksternalisering van die tema onder bespreking;

- Herhalende patrone van magstryd;

- Herhalende patrone van nie luister nie; en

- Herhalende patrone van fokus op kognitiewe inhoud van boodskappe en nie op gevoelens nie.

Vanuit die navorsing blyk dit dat adolessente oneffektiewe interpersoonlike kommunikasiepatrone het. Aanbevelings is gemaak om adolessente se interpersoonlike kommunikasie te fasiliteer binne ' $n$ interpersoonlike kommunikasievaardigheidsbenadering

\section{Backaround and Rationale}

This article focuses on adolescent interpersonal communication patterns (Grobler, 1997). Adolescence is a developmental phase which is characterised by the occurance of many adjustments and changes. Continually higher demands are made to adolescents in terms of career choices, the choice of friends, disengagement from parents and parental homes, and the development of autonomy. Adolescent's sources of support like their families, members of the community and especially the peer group play a significant role during this phase. Interpersonal relationships with these sources of support must be maintained by adolescents during adolescence in order to ensure continued support. This however requires effective interpersonal communication skills.

\section{Problem Statement}

While working with adolescents in the adolescent unit of a psychiatric clinic, the researcher found that adolescents get admitted to these units because of problems like eating disorders, behavioral problems and other psychiatric disorders. Discussions with adolescents within trust relationships however revealed that the problems adolescents present with on admission are secondary to interpersonal relationship problems the adolescents have. These interpersonal relationship problems relate to their sources of support, in example their parents, friends, brothers, sisters, teachers and other people who are important to them. Since successful interpersonal relationships are necessary to successfully complete the developmental phase of adolescence these relationships must be maintained by adolescents in order to ensure continued support. As stated above this requires effective interpersonal communication.

From the above the following research question was formulated: Which iriter- personal communication skills do adolescents have at their disposal?

\section{Objective}

In this article the researcher aimed to: Explore and describe the interpersonal communication adolescents have.

\section{Research design and method}

The research design consisted of a qualitative, investigative, descriptive and contextual design. Trustworthiness was established by utilizing Guba's model for trustworthiness of qualitative research for the validity and reliability of the research. The four criteria for trustworthiness are: truth value; applicability: consistency; and neutrality. The truth value was en sured by using strategies of credibility and applicability by applying strategies of transferability. Consistency was ensured by strategies of dependability and neutrality by strategies of conformability. Table 1 summarizes the strategies utilized to ensure trustworthiness.

\section{Population}

17 year old adolescents from 2 different secondary schools were used for respectively the pre-phase and the data gathering phase of the research.

\section{Sampling Method}

Judgemental sampling was done according to the following criteria:

- Willing participation

- Informed consent from both adolesents and their parents or guardians

- 17 years of age

- Able to speak either Afrikaans or Eng lish

The research method consisted of a prephase where two topical scenarios were formulated within group discussions with adolescents during this pre-phase to be used during data gathering in phase one. The adolescents used for the prephase were from a different school than the adolescents that were used for data gathering. Data gathering consisted of adolescents role playing and writing dialogues according to a given scenario as formulated during the pre-phase of the research. The written dialogues were used for triangulation. The scenario's used were: "You are on your way to a party and your mother doesn't like what you are wearing."; and "Your mother promised you that you can borrow the car. You are on your way out when she tells you that she has changed her mind." 13 Roleplays and dialogues were obtained for data gathering purposes. The role plays were videotaped.

Data analysis was done during phase 2 by transcribing the video recordings and analysing it with the written dialogues according to Tesch's method. Field notes were also taken into consideration. The first step was to read through each individual transcription and written dialogue as well as to watch the actual role play video to get a picture on the whole. The second step was to repeat the first step but to underline individual behaviour patterns which were identified. A list of all the behaviour patterns were made as well as of all the similar behaviour which were related. The most descriptive word for the identified behaviour was sought and placed into categories and sub-categories. Lastly fieldnotes were used to make inferences on behaviour pertaining to the categories and subcategories.

A protocol for analysis of the data was sent to an external data analist who holds a doctorate in psychiatric nursing Consensus was reached between the researcher and the external data analist on the results. A literature control was conducted to identify similarities and the uniqueness of the research.

\section{Results}

The results will now be discussed: The writer will refer to supporting literature and will quote certain portions of the transcribed video recordings and written dialogues. Please note that literature on adolescent interpersonal communication is extremely limited.

The researcher concluded from the results obtained in phase one of the research that the interpersonal communication of the adolescents involved in this research are characterised by four recurrent circular interpersonal communication patterns. These four recurrent circular interpersonal communication patterns are initiated and maintained verbally and non verbally by the adolescents' feelings, thoughts and behaviour. According to Okun(1987: 49) non verbal interpersonal communication hints are given by non verbal behaviour in example body position, the eyes, eye contact, body weight, body posture, mouth facial expression, skin, voice and the all over appearance of the person.

The four recurrent circular interpersonal communication patterns that were identified are

- Defocusing and externalizing the topic under discussion;

- The existence of a power struggle with the conversationist;

- The failure to listen to the conversationists; and

- The lack of focusing on the feelings of 


\begin{tabular}{|c|c|c|}
\hline STRATEGY & CRITERIA & APPLICATION \\
\hline \multirow[t]{2}{*}{ Credibility } & $\begin{array}{l}\text { Prolonged field experience } \\
\text { and observation }\end{array}$ & $\begin{array}{l}\text { Researcher spent time informally with adolescents to gain their } \\
\text { confidence, made video recordings of informal talk and played it } \\
\text { back to adolescents, non-participant observation by researcher, } \\
\text { made use of triangulation(role play and written dialogues), } \\
\text { fieldnotes taken by researcher, literature review done by researcher, } \\
\text { data analysis done by researcher, researcher described findings. }\end{array}$ \\
\hline & Triangulation & $\begin{array}{l}\text { Used two different groups of adolescents for the pre-phase and } \\
\text { phase one of the research, used both video tape recordings as } \\
\text { well as written dialogues during phase one of the research, } \\
\text { fieldnotes, literature review, co-coder used. }\end{array}$ \\
\hline
\end{tabular}

Peer group discussion Researcher had an analytical session with co-coder during phase one. During phase two findings of the research were discussed with a doctoral committee.

Reference adequacy

Annexures of anonymous transcriptions of role plays and written dialogues as well as field notes were attached to research.

Member checking

During phase two findings of the research were submitted to respondents.

Transferability Dense description

Complete description of methodology including literature control and verbatim quotes from role plays and dialogues, broad selection of information for literature control during phase one of the research. Phase two consisted of a dense description of the findings.

Dependability Triangulation

Used two different groups of adolescents for the pre-phase and phase one of the research, used both video tape recordings as well as written dialogues during phase one of the research, fieldnotes, literature review, co-coder used.

Dense description of re- Research methodology fully described. search method

Reference adequacy

Annexures of anonymous transcriptions of role plays and written dialogues as well as field notes were attached to research.

Peer group examination

Research protocol discussed with team of independent nursing specialists.

Peer group discussion

Researcher had an analytical session with co-coder during phase one, during phase two findings of the research were discussed with a doctoral committee.

Consistency

Guidelines for operationalisation of interpersonal communication approach written on findings of phase one.

Confirmability Conformability audit

Independent panel of psychiatric nursing specialists.

Triangulation

Used two different groups of adolescents for the pre-phase and phase one of the research, used both video tape recordings as well as written dialogues during phase one of the research, fieldnotes, literature review, co-coder used.

Peer group discussion

Researcher had an analytical session with co-coder during phase one, during phase two findings of the research were discussed with a doctoral committee.

the conversationists.

Behaviour, feelings and thoughts which initiate and maintain the four recurrent interpersonal communication patterns will now be discussed:

Defocusing and externalizing the topic under discussion: Okun(1987: 25) re- marks that defocusing from the topic under discussion during interpersonal communication is a less positive interpersonal communication skill. Examples of behaviour that initiate and maintain this pattern are the blaming of the other conversationist, signs of adolescents measuring themselves against the con- versationist or other persons and sarcasm.

Robin \& Koepke(1990: 178-215) lists the blaming of others as a negative interpersonal communication skill that compares with the accusing of others, humiliating others, prescribing to others, preaching to others, reading thoughts 
and giving demands to others. An ex ample of how this pattern featured in the research is: "Well, You never wanted me You told Dad that you wanted an abortion, so my style of clothing. It doesn't matter, does it?" Verbal blaming is accompanied by non verbal interpersona communication hints such as looking the conversationist in the eyes while making blamefull statements, speaking louder and leaning forward into the conversationists personal space.

" According to Wayment \& Taylor(1995: 729-757) people who measure themselves against others have a negative self image. An example of how the measuring of themselves against others featured is the following: "Everybody looks like this."

Sarcasm featured in the following way: "It is a dress Mother, what does it look like?"

Sarcasm is accompanied by non verbal interpersonal communication hints such as changed facial expressions, changes in the pitch of voice and the making of eye contact in a challenging way.

Defocusing and externalising the topic under discussion is furthermore initiated and maintained by creating feelings of uncertainty and concern. These feelings are however never spoken of during the dialogues but only implied. These feelings furthermore are never clarified by either of the conversationists which leads to double messages being conveyed, misinterpretations and misunderstandings. Wells \& Miller(1993: 781) describe adolescents' feelings as being more covert. Van der Merwe(1993: 42) states that the lack of having the ability to clarify feelings is the cause of ineffective interpersonal communication.

Examples of how the adolescents created feelings of uncertainty are: "Don't wait up for me, perhaps I am going to be late. "; and "Well the question is whether or not I am going to come back as one. There might just be a "bread in the oven." Non verbal interpersonal communication hints that accompany the above are mostly incongruent laughing or total unemotionality on the part of the conversationist. An example of how the adolescents created concern is the following sentence which was used in order to justify wearing skimpy clothes: "It is in the middle of summer Mom and we are at a party! We are definitely not going to sit still." Non verbally concern is created by adolescents not making full eye contact when asked questions as well as by hesitating when answering.

The thoughts that are responsible for initiating the defocusing and externalis- ing of the discussion are distancing and splitting. Examples of how distancing featured during the research are: "Mom, why must you always be so old fashioned?"; and "No Mom, times have changed!" Non verbally the adolescents created distance by physically distancing themselves from the conversationist as well as by the crossing of arms and by presenting a closed body posture.

According to Kaplan \& Sadock(1995: 250) adolescents use splitting by classifying important persons in their lives as all bad or all good. According to Kaplan et al(1995: 257) this is a defence mechanism used mainly by people during their developmental phase. An example of how splitting featured during the research is: "I put the ring in at Dad's and he didn't mind" ("the ring" refers to a belly ring). Verbal splitting is accompanied by non verbal interpersonal communication hints such as intimidating behaviour when making full eye contact while leaning forward or by declining to make eye contact at all.

The existence of a power struggle with the conversationist: Behaviour that initiate and maintain this interpersonal communication pattern are the adolescents' search for autonomy and independancy, their hard headedness, the use of "you-messages", a display of inadequacy and revengefullness.

Critelli(1987: 223-224) states that dominant remarks lead to dominant reactions. In seeking autonomy and independance the adolescents involved in this research used dominant remarks, which lead to dominant reactions resulting in a power struggle with the conversationist. Examples of how this featured in the research are: "Mom, I am 17 and can do what I want to."; and "Ok, but it remains my choice to decide what I will wear. Remember taste differs, so"

According to Way(1995: 107-128) adolescents agree that the most important aspect to a succesfull relationship is to have an opinion and to be given the oppurtunity to speak your mind on it. Non verbal interpersonal communication hints that accompany the above is a closed body posture, the rising of voice intensity and the interruption of the conversationist.

Dinkmeyer \& Mckay(1995: 11) state that hard headedness is part of the adolescents' strive for autonomy. Examples of how this featured in the research are: "I look normal Mother, and I am leaving now."; and "No, I am taking the car tonight do you hear me? Finished!!" Non verbal interpersonal communication hints that accompany the above are the interruption of the conversationist to give their own opinions and the intensifying of the voice.

"You-messages" leads to aggression and this initiates and maintains the power struggle. Kubany; Richard; Bauer \& Muraoka(1990: 505-516) states that adolescents also verbalise that "you-messages" lead to aversion and antagonism contrary to "I-messages". Also evident from research done by Kubany et al(1992: 505-516) is that "you- as well as I-messages" are used the same amount of times by adoles cents. Okun(1987: 243) states that in making use of "I-messages" one conveyes respect for the conversation ist's opinion. Examples of how you messages featured in this research are: "You don't understand!"; and "You are always so old fashioned!" Non verbal interpersonal behaviour hints that accompanies this include the pointing of an accusing finger at the conversationist as well as making definite eye contact.

According to Dinkmeyer \& Mckay(1990: 12) a display of inadequacy by the adolescents lead to the conversationists feeling sorry for the adolescents. This in turn gives momentum to the already existing power struggle. An example of inadequate behaviour is: "I am sorry Mom, I didn't want to say that. I suppose I have forgotten my manners for a while." Non verbal behaviour hints that accompanies this include not making eye contact, the use of a softer tone of voice and the hanging of the shoulders and head.

Revenge and aggression initiate and maintain the powerstruggle. Both revenge and aggression are more passively shown. Dinkmeyer \& Mckay(1990: 12) are of the opinion that adolescents show the above mentioned behaviour when they feel that they are not going to win the power struggle. Examples of how revenge featured in the research are: "and another thing "grow up""; and "Mom, you had 10 husbands. You used to wear dresses barely covering the "water line". You still wear those "boobtubes" and I don't want to say what else!" An example of how a message that conveys aggression is featured in the research is the following: "I don't want to be forward or anything, it is just that it is always like this and whenever I open my mouth you jump down my throat!" Non verbal behaviour hints that accompanies this are extreme passivity, monotonous tone of voice, the hanging of the shoulders and the eyes being casted downward. Non verbal and verbal messages that are conveyed are absolutely incongruent. Stuart \& 
Sundeen(1995:37) state that incongruency between non verbal and verbal messages creates problems when communicating interpersonally. According to Okun(1987: 62) double messages occur when there is incongruency between non verbal and verbal interpersonal communication.

Feelings that initiate and maintain the power struggle are "don't care feelings", rage, passive aggression, concern, disheartedness and powerlessness. Feelings implied during the role plays were clarified by the researcher with the adolescents directly after the role plays were recorded.

The adolescents experienced "don't care feelings" because they felt that the conversationists did not listen to their opinion. An example of how this featured in the research is: "It does not matter." Non verbally adolescents show their don't care feelings by pulling up their shoulders, the rolling of their eyes and by looking in another direction than that of the conversationist.

Rage was experienced by the adolescents because of the fact that the conversations never resolved anything. According to Van der Merwe(1993: 11) rage originates when a person feels as if someone is denying him/her humanity. Carlson; Mareus-Newhall \& Miller(1990: 622-633) state that verbalizations because of rage give leadway to rage becoming aggression. A verbal example of how rage featured in the research is: "Now I know what you think of the way in which I dress Mother! What gives you in any way the right to say something about my clothes when you are not in fashion since a long time ago!" Non verbal behaviour accompanying this include incongruent voice intensity and an over controled way of speech. Hands are not used and this shows the passivity of the way in which the adolescents experience their rage.

The power struggle is maintained through the passive aggressive way the adolescents handle their aggression. By not talking about feelings the power struggle is maintained. An example of how passive aggression featured in the research is the following: "If it is that important to you Mother, I suppose I will have to do it. I suppose there is no other way." Non verbally adolescents' voices are incongruent with their actual feelings in that they speak softly and in an over controlled manner and hands are not used during verbal statements. Contrary to the above mentioned observation Wells \& Miller(1993: 781) describe adolescent aggression as behaviour one can definitely see.
The adolescents introduced feelings of concern to the conversationist in the research by giving only limited information on his or her where abouts and implying the rest. The adolescents also answered questions of the conversationist as shortly as possible. An example of how the above featured in the research is: Mother: "I don't think it is a good idea that he drives you. What is going on in this life?" Adolescent: (laughs) "Nothing." Non verbal behaviour that accompanies this include adolescents acting as if they have secrets as well as laughing incongruently.

Disheartedness and powerlessness are also never mentioned, but just implied. An example of how this featured in the research is: " but Mom, you promised!" Non verbaly disheartedness and powerlessness are shown by a passive body position, eyes that are focused on the ground, the dropping of shoulders and sighing now and then.

Thoughts that keeps the powerstruggle alive are conflicting values that the adolescents seem to have with the conversationist'. A verbal example of how this featured in the research is: "What do you think of me Mother?" Okun(1987: 241242) states that if you are aware of your own values you are less likely to impose them indirectly on others and that confusion regarding values usually results in interpersonal difficulties.

The failure to listen to the conversationist: According to Van der Merwe (1993: 11) the inability to listen causes ineffective interpersonal communication. Behaviour that cause adolescents not to listen effectively during interpersonal communication are the adolescents' search for autonomy and independence, sarcasm, the adolescents' attempt to clear problems and too few silences during communication. The pre-occupation the adolescents have with their own goals cause them not to listen(Stuart \& Sundeen, 1995: 39; Morrison \& Burnard, 1991: 75). Non verbal behaviour pertaining to the adolescents own intentions are that they interrupt the conversationists constantly and their voices intensify when they make verbal statements. Sarcasm plays its role in that the adolescents do not listen to the conversationist but rather think of the best answer to give on the statement the conversationist has made. Non verbally not much eye contact is made by the adolescents and the intensity of voice differs drastically from that of a normal conversation. The adolescents seem apathic overall, however facial expressions tend to change with the use of sarcasm. Adolescents try to clarify problems with the conversationists but fail due to the fact that they do not listen to the conversationists. An example is: "What is wrong with my clothes Mother?" Non verbally behaviour hints that accompany this are that the adolescents' voices intensify while trying to clarify problems. Beaumont(1995: 109-132)concludes that adolescents' conversations are characterised by them interrupting the conversationists' conversations. By using too few silences the adolescents don't give themselves time to listen to the conversationist.

Feelings of uncertainty and concern also maintains the pattern of failing to listen in that nothing is clarified, but only implied. The more questions the conversationist put to the adolescents in the research the shorter the answers became and the more concerned the conversationist became. Verbal examples of how this featured in the research are: Mother: "Who will pick you up?" Adolescent: "Tokkie" Mother: "Tokkie who?" Adolescent: "Prozesky" Nonverbal behaviour seem to be incongruent with verbal messages characterised by incongruent laughing or statements without any sign of emotion.

Thoughts that initiate and maintain the circular pattern of failing to listen are the adolescents' use of their own special language and their making use of short sentences. Examples of adolescents' own language are: "ok", "boob-tubes", "minded", "bread in the oven", "allright", "hike", "fun". Non-verbally it seems as if this "own language" gives the adolescents some kind of autonomy and feeling of independence. The non-verbal behaviour that accompanies the use of short sentences, are the fact that very few silences are used in between these short sentences. Beaumont's(1995: 109-132) research confirms the above.

The lack of focusing on the feelings of the conversationist: Hodge et al(1981: 9)state that messages carry much more interpersonal content than cognitive content does. Behaviour that initiate and maintain this communication pattern are the adolescents' search for autonomy and independence as well as their endeavor to resolve problems. Inspite of the adolescents' endeavor and intention to solve a problem, he fails to do so due to the fact that communication is focused on the cognitive message and not on the feelings contained in the message. A verbal endeavour to do problem solving featured in the research with: "What is wrong?" Non verbally the intensity of the adolescents' voices intensify when trying to do problem solving.

Feelings of "don't care", rage, passive 


\section{Subscribe to Curationis}

\section{Curationis Subscription Form}

I would like to subscribe to Curationis.

Enclosed please find the prescribed subscription fee.

R80 as a member of DENOSA - membership number

R120 as a non-member of DENOSA

$\square$ \$US 45 as an international subscriber

I am forwarding my subscription fee in the form of:

Cash

Cheque

Postal order

Other (please specify)

\section{Declaration by Tertiary Institution}

I, herewith declare, that the person whose particulars appear on this subscription form, is a bona fide nursing student at this tertiary institution who qualifies for $10 \%$ discount.

Name of Institution

Signature \& Capacity

Please post my Curationis to:

$\mathrm{Prof} / \mathrm{Dr} / \mathrm{Mr} / \mathrm{Mrs} / \mathrm{Miss} / \mathrm{Ms}$

Code

Cheques/postal orders/money orders must please be made payable to: DENOSA Post the subscription form together with you payment to:

The Editor, Curationis, PO Box 1280, Pretoria, 0001, SA. 


\section{Curationis Research Register}

\section{New/Ongoing Research}

Reference number (for office use only)

Name(s) and initial(s) of researcher(s)

\section{Contact particulars of researcher}

Telephone

Facsimile

E-mail

\section{Reason for doing research}

Post-Doctoral Research

Research towards Doctoral Degree

Research towards Master's Degree

Research towards Honours Degree

Research towards Basic Degree

Research towards Diploma/Certificate Programme

Other research, e.g. contract, etc. (please specify)

Name of institution under whose auspices the research will be conducted e.g. Name of University/Technikon/College/ Institution/Other (please specify)

Provisional title of research

Brief summary of purpose of research (Maximum 50 words)

(please use seperate page)

\section{Completed Research}

Reference number that was allocated to your research submission

Name(s) and initial(s) of researcher(s)

Contact particulars of researcher

Telephone

Facsimile

E-mail

Reason for completed research

Post-Doctoral Research

Research towards Doctoral Degree

Research towards Master's Degree

Research towards Honours Degree

Research towards Basic Degree

Research towards Diploma/Certificate Programme

Other research, e.g. contract, etc. (please specify)

Name of institution under whose auspices the research was conducted e.g. Name of University/Technikon/College/Institution/Other (please specify)

Final title of research

Brief summary of research (Maximum 250 words) (please use seperate page) 


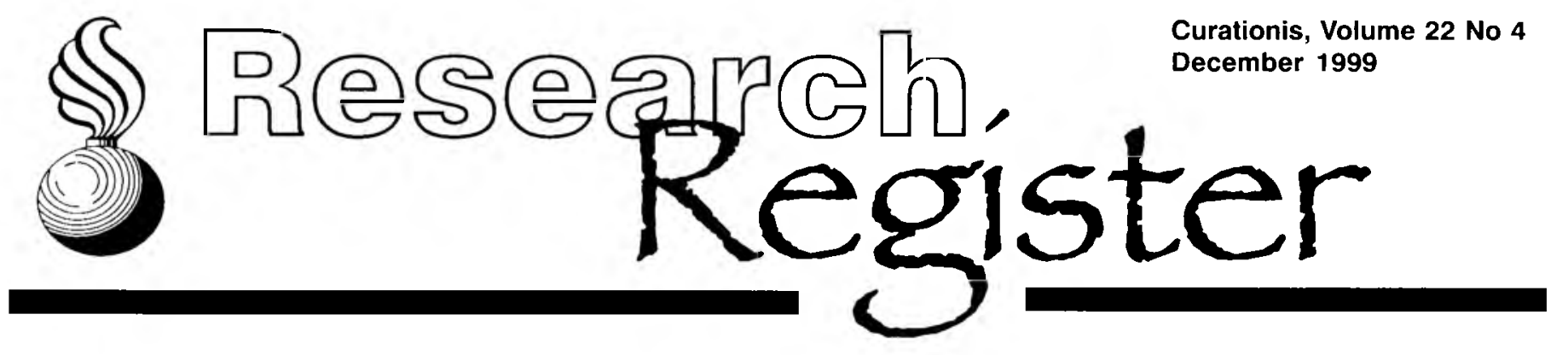

\section{New / Ongoing Research}

1999/01

LANGLEY, GC

Tel: (011) 488-4271 Fax: (011) 488-4195

E-mail <llolang@chiron.wits.ac.za>

University of the Witwatersrand

Doctoral: Borderline personality disorders: factors contributing to health maintenance and stability.

1999/02

PELTZER, $\mathrm{K}$

Tel (015) 268-2316 Fax: (015) 268-2320

E-mail <peltzerk@unin.unorth.ac.za>

University of the North

Post-Doctoral: Non pharmacological management of hypertension and diabetes in the Northern Province.

1999/03

PELTZER, $\mathrm{K}$

Tel (015) 268-2316 Fax: (015) 268-2320

E-mail <peltzerk@unin.unorth.ac.za>

University of the North

Post-Doctoral: Improving the DOT strategy for the treatment of tuberculosis patients.

\section{9/04}

COETZEE, IM

Tel: (012) 354-2125 Fax: (012) 354-1490

E-mail <nursing@medic.up.ac.za>

Rand Afrikaans University

Master's: Kliniese leeruitkomste vir die kritiekesorg praktyk. Kliniese leeruitkomste gaan gestel word vir die verskillende dissiplines binne die kritiekesorgpraktyk, sodat die kritiekesorg leerder weet aan watter uitkomste sy/hy moet voldoen as hy/sy in die spesifieke eenhede gewerk het. Die preseptore kan dan ook die kliniese leeruitkomste gebruik as riglyn vir kliniese begeleiding.

\section{9/05}

MUYEU M

Tel: $+067255025 \times 2260$

University of Namibia

Master's: The quality of nursing care regarding the personal hygiene of patients admitted to a hospital in the Kavango region.

The purpose of the study is to identify through a survey the quality of nursing care regarding personal hygiene in a hospital in the Kavango region.

\section{9/06}

ROBERTSON S

Tel: (011) 488-4272/3

Fax: (011) 488-4195

E-mail<llosnar@chiron, wits.ac.za>

University of the Witwatersrand

Master's: Experiences of undergraduate nursing students of their problem-based, community-based approach to learning. The purpose of the research is to explore the experiences of students by getting them to share their perceptions and experiences in order to attempt to describe the experiences from the student's point of view. The purpose is also to provide a more relevant support programme for those who really struggle.

1999/07

RICHTER, MS

Tel: (012) 354-2125 Fax: (012) 354-1490

E-mail <mrichter@medic.up.ac.za>

Rand Afrikaans University

Doctoral: Ontwikkeling van standaarde vir perinatale onderrig op nasionale vlak.

Daar bestaan geen standaare vir perinatale onderrig in SuidAfrika nie. Die doel van hierdie navorsing is om standaarde te ontwikkel met die doel om as riglyne te dien vir ' $n$ kwaliteit diens wat die reg is van elke swanger vrou en vrou met kinders.

1999/08

PRETORIUS, L

Tel: +264 $61206-3170$

Master's: The role of the clinical instructor in the development of critical thinking of student nurses.

The purpose of the study is to describe the role of the clinical instructor in the development of critical thinking of student nurses.

1999/09

VAN VELDEN, CE

Tel (012) 993-4598 Fax: (012) 354-1490

E-mail <nursing@medic.CvanveldUP.ac.za>

University of Pretoria

Other Research: Die keuring van B.Cur. studente aan die Universiteit van Pretoria in perspektief.

Voorgraadse studente aan die Universiteit van Pretoria word die afgelope 15 jaar volgens ' $n$ aangepaste Smeltzer-skaal gekeur. Die effektiwiteit van die keuringsmodel word ondersoek in terme van akademiese sukses asook koste-effektiwiteit

1999/10

BESTER, $M$

Tel: +264 61 206-3206

University of Namibia

Master's: The standard of nursing care of patients undergoing hysterectomies in training hospitals in Windhoek.

The purpose of the study is to investigate the extent to which the standard of nursing care of hysterectomy patients, in training hospitals in Windhoek, meet set criteria.

$1999 / 11$

VAN WYK, N.C. (PROF)

Tel: (012) 354-2125 Fax: (012) 354-1490

E-mail <nvanwyk@postillion.up.ac.za>

University of Pretoria

Post-Doctoral: A model for the training of reflective nurses.

The purpose of the research is to develop a model incorporat- 
ing the theory of conscientisation developed by Paolo Freire for the training of reflective practitioners.

$1999 / 12$

KLOPPERS, $J$

Tel: +264 61 206-3224 Fax: +25461 206-3922

University of Namibia

Master's: An investigation into the health needs and experiences of children in foster homes in Windhoek.

The puspose of the study is to gather information on the health needs and experiences of children in foster homes in Windhoek.

\section{$1999 / 13$}

PULLEN, AE

Tel: (012) 373-8041 Fax: (012) 373-9031

E-mail <apullen@kalafong.up.ac.za>

University of Pretoria

Doctoral: A model for an enrichment programme for registered nurses in a hospital context.

The purpose of the study is to develop a model for an enrichment programme for nurses, to enable them to fulfil their professional role.

1999/14

CHAUKE, EM

Tel: (012) 320-3275

University of Pretoria

Master's: Adaptation of lodger mothers after prolonged rooming in with their hospitalised neonates at Garankuwa Hospital. The aims of the study are to describe how mothers who roomedin for a month or more adapt at home after discharge and to identify problems related to physical care of babies which they experienced after discharge.

$1999 / 15$

ANGALA, SP

Tel: +264 61 30-4078 (home)

University of Namibia

Master's: A survey on the knowledge and experiences of newly diagnosed tuberculosis patients and health workers about the management of tuberculosis.

The purpose of the study is to gather the relevant information and possibly recommend the development of an educational tool to supplement daily patient education.

1999/16

BAIRD, AC

Tel: (012) 354-2129 Fax: (012) 354-1490

E-mail: <annab@netactive.co.za>

University of Pretoria

Other Research: Nursing dynamics: telematic education - a comparative study concerning paper based versus transmission only method of teaching.

The purpose of the study is to estimate the value of paper-based telematic education regarding nursing dynamics.

\section{$1999 / 17$}

MOETI, MA

Tel: (012) 354-2125

University of Pretoria

Master's: The perceptions of the realisation of the scope of practice of the registered nurse in newly graduate nurses.

The purpose of this study is to describe the perceptions regarding the realisation of the scope of practice of the registered nurse in newly graduated nurses.
Tel: +264 61 203-2395

University of Namibia

Master's: The management of iron/folate supplementation for pregnant women by registered nurses and midwives in maternity services in Windhoek.

The purpose of the study is to obtain information on the management of iron/folate supplementation in pregnant women by registered nurses and midwives.

\section{9/19}

RAMAKGOAKGOA, M

Tel: (012) 318-6851

University of Pretoria

Master's: Experiences of women who had abortion by choice. The purpose of the study is to explore the experience of women who had abortion by choice regarding the procedure of abortion.

1999/20

SATEKGE, $M$

Tel: (011) 923-2108

University of Pretoria

Master's: The lived experience of teenage pregnancy.

The purpose of the study is to describe the lived experience of teenage pregnancy in a rural African community.

\section{$1999 / 21$}

TEMPLETON, LE

Tel: (011) 314-2671

University of Pretoria

Master's: The realisation of conscientisation during sustainable community development: a participatory research approach.

The aims of the study are to analise the process of conscientisation according to Paolo Freire's theory of conscientisation, as it manifested itself in the participants of the study and to describe the realisation of the process of conscientisation as perceived by the facilitators of the community development that occured.

1999/22

THAKHISI, YM

Tel: +09266 331901

University of the Witwatersrand

Master's: Knowledge, attitude and risk behaviours for contracting HIV/AIDS infection among adolescents in schools in Lesotho.

The study seeks to reveal what knowledge high school students have regarding HIVIAIDS and how the students apply the knowledge they have bout HIVIAIDS in their daily lives.

\section{9/23}

MGOMA,B

Tel: (011) 955-2161

University of the Witwatersrand

Master's: Record review of absenteeism in a paint factory. The research seeks to establish the reasons associated with absenteeism and to develop a health programme that may help to control and/or reduce absenteeism.

1999/24

MOLISE, N.A

Tel: +09266 31-4608Fax: +09266 31-7671

University of the Witwatersrand 
Master's: Occupational hazards among nurses in a large referral hospital in Lesotho.

The purpose of the study is to collect baseline data on occupational risks that nurses are exposed to in order to motivate for the establishment of an occupational health service.

\section{9/25}

RAMAKUMBA, TS

Tel: (012) 529-3205 Fax: (012) 560-0099

University of the Witwatersrand

Master's: An investigation into the knowledge mothers of under 2-year old children have of the 'road to health' chart in a tertiary health care unit in Garakuwa.

The purpose of the study is to determine the knowledge of mothers and their understanding of the use of the 'road to health' chart in the health maintenance of their children.

\section{9/26}

ZIMBA, EW

Tel: (011) 488-4272 Fax: (011) 488-4195

E-mail<llonrse@chiron,wits.ac.za>

University of the Witwatersrand

Master's: Knowledge of primary caregivers on home-based care of HIV/AIDS children in Malawi.

The study aims to determine the knowledge of the primary caregivers of children HIVIAIDS.

\section{9/27}

BRAND, CE

Tel: (051) 507-3429 Fax: (051) 507-3355

E-mail<cbrand@mail.tofs.ac.za>

Technikon Free State

Doctoral: Synergism between antioxidants in wines, vitamins and fatty acids.

The French paradox: is it only red wine giving protection against heart diseases or does it also include the other eating habits? For that reason it is intended to include vitamins and different fatty acids, especially olive oil in the conjugated diene method.

\section{9/28}

NYUSWA, NV

Tel: (031) 907-8111 Fax: (031) 907-8334

University of Zululand: Durban-Umlazi Campus

Master's: Management and health information systems in Health Region F of KwaZulu-Natal hospitals.

The purpose of the study is to identify tools to improve inadequate analysis, interpretation and utilisation of data on health and health care. It is also intended to identify strategies that can be used to facilitate a well co-ordinated, comprehensive and user-friendly management and health information system in KwaZulu-Natal.

\section{9/29}

\section{GUMEDE, EZ}

Tel: (0325) 3-4086

University of Zululand: Durban-Umlazi Campus

Master's: Implementation and the effectiveness of affirmative action in achieving employment equity in the public and private health sector in KwaZulu-Natal.

The purpose of the study is to identify the extent to which the affirmative action strategy is adopted in these services, to identify factors that facilitate or hinder its success and its implications for the quality of heat/h care.

\section{$1999 / 30$}

GUMEDE, ZNE

Tel: (03431) 4-9221

University of Zululand: Durban-Umlazi Campus

Master's: The preparedness of professional nurses in terms of human resource development strategy for the transforma- tion of health care in KwaZulu-Natal province.

The purpose of the study is to evaluate if the existing human resource development strategies are adequate and appropriate to prepare professional nurses to function effectively in the transformed health care system in South Africa, with particular reference to the primary health care philosophy.

\section{9/31}

NYEMBE, LN

Tel: (031) 907-8111 Fax: (031) 907-8334

University of Zululand: Durban-Umlazi Campus

Master's: Home based care as a continuum of the comprehensive health care provision for people living with AIDS at Umlazi Health Region F, KwaZulu-Natal.

The aim of the study is to determine the appropriateness of care provided for people living with AIDS at home and to determine the type and extent of support they get.

1999/32

KHANYILE, TO

Tel: (031) 777-1155

University of Zululand: Durban-Umlazi Campus

Master's: The effectiveness of the directly observed treatment short course (DOTS) strategy for control of tuberculosis in the Outer West Health District of KwaZulu-Natal

The purpose of the study is to investigate the treatment outcome of patients enrolled in the DOTS programme from the perspective of those involved in its implementation as providers and consumers. Problems will be identified and recommendations made for improvement where necessary.

\section{$1999 / 33$}

KUBHEKA, BA

Tel: (031) 907-7-76 Fax: (031) 907-3011

University of Zululand: Durban-Umlazi Campus

Doctoral: An evaluation of the impact of post basic nursing programmes of the University of Zululand.

The purpose of the research is to evaluate the appropriateness of the utilisation of the post-basic nursing programmes of the University of Zululand. It is also to find out how the graduates of the University are utilised in the health services and the nursing education institutions of KwaZulu-Natal. 


\section{Completed Research}

\section{9/34}

MOTAUNG, MJ

Tel: (012) 521-4476

University of Pretoria

Master's: Learning styles of students at nursing colleges associated with MEDUNSA.

A descriptive survey was conducted in Bafokeng, Ga-Rankuwa, Gazankulu and Kangwane nursing colleges. The data was gathered with the help of a questionnaire. Random sampling method was used to select $10 \%$ of the total population for the pilot study, to test for validity and reliability. Of the 284 questionnaires distributed to the four colleges to first year and fourth year students respectively, a usable response of 284 (100\%) was obtained. The results indicated that every individual student uses more than one learning style. There is no significant difference between fourth year male and female students' learning styles when compared to those of first year students. Therefore, nurse teachers should use many teaching strategies during the teaching process in order to enhance learning. Students should as well change or modity their learning styles in relation to the teaching styles of their teachers and this will improve learning and teaching. It is recommended that a study on identification of teaching strategies used at various nursing colleges be done. Identification of learning styles of each student and compari-. son thereof should also be done at different year levels of training.

\section{9/35}

\section{KUNENE, PJ}

Tel: (031) 907-7077 Fax: (031) 907-3011

University of Zululand: Durban-Umlazi Campus

Doctoral: Perceptions on the impact of nurses' strikes on nurses, the nursing profession and on quality of health care in KwaZulu-Natal Province.

The aim of the study was to pursue an exploratory, descriptive case study to investigate perceptions on the impact of nurses' strikes on nurses, the nursing profession and on the quality of health care. A purposive sample was selected from a population consisting of nurses, nursing management, officials of the Provincial Health Department, chairpersons of two nursing representative organisations and community members as consumers of health care. For the purpose of the investigation semistructured interviews were utilised. The study revealed that perceptions on nurses' strikes were not typical of any particular group. Similarities and differences were noted within and between groups. It was found that job dissatisfaction remains prevalent among nurses in spite of acknowledged attempts at addressing job dissatisfiers. Negative feelings and views about nurses' strikes persist, mainly because of the adverse impact on consumers of health care. It was evident that management and employers face greater challenges in prevention of strikes. Based on the perceptions and suggestions of the participants, a model entitled 'The Integrative-Development-Adaptive (IDA) Strike Model' was constructed It emphasises the need for coordinated training and development programmes to facilitate an integrative approach and continuous adaptation by all healthcare stakeholders to the various factors that precipitate or trigger strike action. This model is applicable before, during and after strikes.

\section{9/36}

LIONJANGA, R

Tel: (+09267) 21-4717

University of the Witwatersrand

Master's: The cultural beliefs and practices amongst urban antenatal Botswana women in Francistown City.

The purpose of this non-experimental descriptive study was to identify the cultural beliefs and practices surrounding pregnancy. The study aims at collecting data which will function as baseline information on cultural beliefs and practices surrounding pregnancy. A structured interview guide with both open and close-ended questions was used to collect data from 230 pregnant women who were 18 years of age and older and who were wiling to participate. The data was processed on computer and a statistical software package known as 'Statistical Package for Social Sciences (SPSS) ' was used. The study revealed that pregnant women used a combination of care givers which either included a modern midwife and an elderly woman at church or a modern midwife and a traditional midwife. This is done in order to follow the traditional and cultural beliefs surrounding pregnancy and childbirth. The majority (92,2\%) of the antenatal women in this study had primary and secondary education but still followed their cultural beliefs and practices. Thus, education does not appear to influence cultural beliefs and practices. The most common reasons cited for adhering to the beliefs and practices were that defiance was a taboo punishable by the ancestors. This study has highlighted the cultural beliefs and practices related to pregnancy. Further in-depth investigation into the impact of these cultural beliefs and practices is needed as it is imperative to determine their impact on pregnancy and its outcome. The limitation of the study was that data was only collected in one city and, therefore, the results cannot be generalised to the entire population.

\section{$1999 / 37$}

RAPINYANA, O

Tel: +09267 21-3136Fax: +09267 21-5328

University of the Witwatersrand

Master's: Postpartum women's perceptions of early discharge from hospital.

The purpose of the study was to investigate women's perceptions of early discharge after childbirth and to determine their needs. The study aims to create an awareness that could lead to improved service and meet the needs of postnatal women. A descriptive survey design was used in order to study the views of postpartum mothers in relation to early postpartum discharge. The target population was postnatal mothers six weeks postdelivery. Simple random sampling was used to select five clinics for the study. Convenience sampling was used to select a sample of at least 22 postnatal women from each clinic. A sample of 110 post-natal women was obtained from five clinics. A structured interview schedule was used and both open and close-ended questions were utilised. The findings of the study revealed that respondents felt that it was good to be discharged early in order to join their families at home for support. Those respondents who felt it was not good, felt that they lacked information and basic skills in relation to care of their babies and self. The findings further showed that primiparae experienced stressful events post-delivery for example, tearfulness. The limitations are that the study was conducted in only one urban setting, there, the findings cannot be generalised beyond the sample. The findings of this research are also limited to the five clinics. It is recommended that each postnatal ward should have a teaching manual which provides instruction or information that must be given by the midwives to the postnatal women. It is also recommended that the needs of the mothers be recognised, so that information given is individualised. It is further recommended that a similar study be conducted on teenage mothers to identify problems of grous with special needs. 
aggression and uncertainty also initiate and maintain the recurrent interpersonal communication pattern of failing to focus on feelings. By not discussing feelings but by only implying them, the above mentioned pattern keeps evolving during adolescent interpersonal communication.

Adolescent thoughts that initiate and maintain the abovementioned recurrent interpersonal communication pattern are thoughts on problemsolving and compromising. These thoughts lead to nothing when they are not focussed on the emotional content of messages. Examples of verbal compromise are: "Compromize? Well that sounds OK, I accept that."; and "Ok, I will try to make another plan."

\section{Conclusion}

The above conclude the findings of this research. The researcher believes that the adolescents have the ability to formulate constructive interpersonal communication skills if they are given the oppurtunity and are fascilitated corrrectly. The adolescents' verbalised their dissatisfaction with their way of interpersonal communication can be utilized in an approach to fascilitate adolescents into formulating constructive interpersonal communication skills.

\section{Limitations}

A possible limitation to this study is the use of video recordings as data gathering method, since video recordings could have made the adolescents anxious an could have influenced the way in which they communicated with one another. This limitation was however put aside in putting the adolescents at ease by allowing them to watch themselves on a TV screen as they entered the room and while having informal conversation. Triangulation through the written dialogues that were done together with the videotape recordings also makes the above possible limitation less of a concern.

\section{Recommendations}

Recommendations were made for psychiatric nursing practice, -research and -education:

Psychiatric nursing practice: Knowledge of the adolescents' interpersonal communication patterns enable the psychiatric nurse to fascilitate adolescents in becoming more effective interpersonal communicators.

Research: Data gathered in phase 1 of this research is rich in information on adolescent interpersonal communication which is an understudied field of research, thus other research can be con- ducted on this data. Guidelines can be described for the operationalization of an interpersonal communication approach for adolescents which could be put into practice and which can then be described within a single case study.

Nursing education: Nursing students can be made aware of the communication patterns that adolescents use to enable the students to fascilitate more effective interpersonal communication in their clients.

\section{Sources}

BEAUMONT, S.L. 1995: Adolescent girl's conversations with mothers and friends: a matter of style. Discourse Processes, 20(1):109-132, Jul/Aug.

CARLSON, M., MAREUS-NEWHALL, A. \& MILLER, N. 1990. Effects of situational aggressive cues: a quantitative review. Journal of Personality and Social Psychology, 58: 622-633.

CRITELLI, J.W. 1987. P.ersonal growth and effective behaviour. New York: Holt, Rinehart \& Winston.

DINKMEYER, D. \& MCKAY, G.D. 1990. Parenting teenagers. Circle Pines, Minnesota: American Guidance Service.

HODGE, B., MALCOLM, I. \& COURTS, D.C. 1981. Communication and the teacher: language and communication for teachers. Melbourne: Longman Cheshire.

KAPLAN, H.I. \& SADOCK, B.J. 1995. Synopsis of psychiatry. Baltimore: Williams \& Wilkens.

KUBANY, E.S. RICHARD, D.C., BAUER, G.B. \& MURAOKA, M.Y. 1992. Verbalized anger and accusatory 'you' messages as cues for anger and antagonism among adolescents. Adolescence, 27(107):505-511, Fall.

OKUN, B.F. 1987. Effective helping interviewing and counseling techniques. California: Brooks/Cole Publishing Company.

MORRISON, P. \& BURNARD, P. 1991. Caring and communicating: the interpersonal relationship in nursing. London: The Macmillan Press Ltd.

ROBIN, A.L. \& KOEPKE, T. 1990. Behavioral assessment and treatment of parent-adolescent conflict. (In Hersen, M., Eisler, M. \& Miller P.M.(Eds). Progress in behavior modification. Canada: Sage.)

STUART, G.W. \& SUNDEEN, S.J. 1995. Principles and practice of psychiatric nursing. USA: Mosby Yearbook Incorporated.

VAN DER MERWE, M.P. 1993. Uitnodigende kommunikasie in die onderwys. Johannesburg: Randse Afrikaanse Universiteit (DEd-proefskrif).

WAY, N. 1995. "Can't you see the Courage, the Strength that I Have?": Listening to Urban Adolescent Girls speak about their Relationships, Psychology-ofWomen-Quarterly, 9(1): 107-128.

WAYMENT, H.A. \& TAYLOR, S.E. 1995. Self-evaluation processes: motives, information use, and self-esteem. Journal of Personality, 63(4):729-757, Dec.

WELLS, D. \& MILLER, M.J. 1993. Adolescent affective aggression: an intervention model. Adolescence, 28(112):781-791, Winter. 